\title{
THE WILLINGNESS AND PREPAREDNESS OF LOCAL GOVERNMENTS IN AP VOJVODINA/SERBIA TO GRIP AND USE DEVELOPMENT FUNDS OF THE EUROPEAN UNION
}

\author{
Imre NAGY ${ }^{\mathrm{a}}$, András RICZ \\ ${ }^{a}$ University of Novi Sad, The Faculty of Sciences, Department of Geography, Tourism and Hotel \\ Management, nagyi@rkk.hu \\ ${ }^{\mathrm{b}}$ Széchenyi István University, Győr, Doctoral School of Regional Economics and Business \\ Administration, riczandras@rcgroup.co
}

Cite this article: Nagy, I., Ricz, A. (2017). The Willingness and Preparedness of Local Governments in Ap Vojvodina/Serbia to Grip and Use Development Funds of the European Union. Deturope, 9, 2: 118-128

\begin{abstract}
EU funds that are available in Serbia are modest both in volume and number, since Serbia received preaccession status only in 2014. Before that, it was only a potential pre-accession country on the external border of the European Union. From the five components of IPA (2007-2013) Serbia could have utilised only the first two components in the pre-accession process: building of EU institutions (EXCHANGE IIV, Regional Socio-Economic Development Programme) and enhancing cross-border cooperation As a conclusion we can say that although substantial sums were invested from the above mentioned resources into the economy of Vojvodina for its development, the main indicator - the GDP - has been increasing only slightly, while these projects have no effects on decreasing unemployment. In the overall economic situation, unemployment is primarily decreased by emigration, in which Vojvodina Hungarians take part at a rate above the average compared to their headcount, thus decreasing the economic power of the community through emigration.
\end{abstract}

Keywords: Vojvodina/Serbia, EU subsidies, local governments

\section{INTRODUCTION}

After the political changes in Serbia in 2000, the European Union provided programming opportunities to the Autonomous Province of Vojvodina already in 2003, followed by available development funds within PHARE CBC programme in 2004 and 2005, while the province as a bordering region of Hungary and Romania got additional development subsidies from 2006 to 2009 due to CARDS programmes.

In the 2007-2013 programming period, development resources were available to Serbia in two components of the IPA11 programme (Transition Assistance and Institution Building; Cross-Border Co-operation). These funds were at disposal not only to Vojvodina, but to Serbia and its neighbours as well, within cross-border programmes, while they also enabled development projects inside the country. This programme has been of greater importance to

\footnotetext{
${ }^{11}$ Instrument for Pre Accession Programme
} 
Vojvodina, since it is bordering with Hungary, Romania, Croatia, and even with Bosnia and Herzegovina on a shorter border section, thus the implementation of IPA CBC programmes could have started (Ricz-Nagy-Juhász, 2015).

\section{EU subsidies available in Serbia}

EU funds that are available in Serbia are modest both in volume and number, since Serbia received pre-accession status only in 2014. Before that, it was only a potential pre-accession country on the external border of the European Union. In the following subsection we enumerate the most important EU programmes where municipalities from Vojvodina could apply.

IPA (2007-2013)

IPA is the Instrument for Pre-Accession provided by the EU, which substitutes a range of community programmes and financial resources intended for candidate and potentially candidate countries. It primarily helps the building of pre-accession institutional capacities, being expected to lead to positive and progressive development in the region and in the acceding states.

From the five components12 of IPA (2007-2013) Serbia could have utilised only the first two components in the pre-accession process: building of EU institutions (EXCHANGE I-IV, Regional Socio-Economic Development Programme) and enhancing cross-border cooperation.

\section{Exchange I - IV}

The topics of this programme are aimed at novel and effective management in local governments, involving developments in work organisation of financial, economic, educational, communal, environmental, and local government offices. EXCHANGE I was intended for improving innovative customer service in local governments, presenting local officers the best practices of local governments in EU Member States. In the framework of the Permanent Conference of Cities, EXCHNAGE II supported capacity building of local selfgovernments and the harmonisation of national and EU legislation, which resulted in the

\footnotetext{
${ }^{12}$ The IPA 2007-2013 (IPA I) is made up of five different components: 1. Assistance for transition and institution building; 2. Cross-border cooperation (with EU Member States and other countries eligible for IPA); 3. Regional development (transport, environment, regional and economic development); 4. Human resources (strengthening human capital and combating exclusion); 5. Rural development.
} 
completion of the Serbian Local Development Rules for the Serbian local authorities, containing the standards of local planning. EXCHNAGE III supported the participation of local governments in decentralisation processes in accordance with EU standards and their further capacity building.

\section{Regional Socio-Economic Development Programme}

The key objective of the IPA I Regional Socio-Economic Development Programme was to support balanced regional development in favour of EU accession through the promotion of regional development agencies, support for the development of inter-municipal relations and the promotion of Grant Schemes.

Until the completion of the RSEDP programme, the EU Delegation in Serbia had continuous cooperation with the Ministry of Economic and Regional Development and the National Agency for Regional Development, as well as with local governments and regional development agencies, in order to strengthen the capacities needed to prepare spatial development strategies that are in line with national development priorities and are reflected in local and regional programmes and projects, thus contributing to the creation of a business environment with same opportunities, competitive operation and balanced territorial development.

\section{IPA I (Component 2) - Assistance to cross-border cooperation}

Component 2 focuses on strengthening cross-border links through joint local and regional initiatives, aimed at sustainable economic, social and environmental development in the fields of environment and nature conservation, common cultural heritage protection, public health, fight against organised crime and safe border protection, as well as supporting local initiatives in the common border region.

\section{Europe for Citizens (program directly from Brussels)}

The aim of the programme is to get the citizens acquainted with the EU and its history, to present the differences and varieties within the EU, as well as to promote the conditions for citizens' and democratic participation, over building Europe awareness and European values, and preparing for intercultural dialogue. 


\section{SEE - South East Europe programme}

This programme for interregional cooperation supported joint development projects of the Western Balkans and the Central and Eastern Europe. The SEE programme is the continuation of the CADSES programme.

\section{The impact of $\mathbf{E U}$ subsidies in Serbia concerning local governments}

The number of projects implemented by local governments (municipalities) was 256 . However, regarding the size and spatial distribution of subsidies, there are large differences in Vojvodina. In the last planning cycle, the Local Government of Novi Sad realised 21 projects, but the project implementation of the municipalities of Vršac (18), Zrenjanin (15), Pančevo and Kanjiža (14) was also significant. By contrast, five local governments (Bačka Palanka, Bečej, Odžaci, Opovo and Srbobran) realised only one project each, while Titel had no EU projects at all (EUV, 2015).

Most of the project proposals (45) were realised in the field of economic development, slightly fewer projects were used for municipal development, or they were related to environmental protection, nature conservation and alternative energy sources (42-42), while the least number of projects were the educational ones.

Considering the theme of the projects, infrastructural development ones are predominant (31), followed by social and health protection (30), tourism (23) and cultural cooperation (15). With respect to municipalities, the largest investments were implemented in Vrbas and Kula (construction of a central sewage treatment plant for EUR 23.6 million).

According to the survey, in 92 of the 256 projects municipalities from Vojvodina were the lead beneficiaries.

Determining the total amount of projects is difficult because there is no consistent record of the projects belonging to different programmes. Based on the above mentioned study, the total value of EU projects in which Vojvodina municipalities participated in the period between 2007 and 2013 is EUR 120,575,188.29. It is estimated that about two thirds of this amount fall on municipalities from Vojvodina (EUV, 2015). 
Figure 1 Projects financed by the EU according to their types, 2007-2013

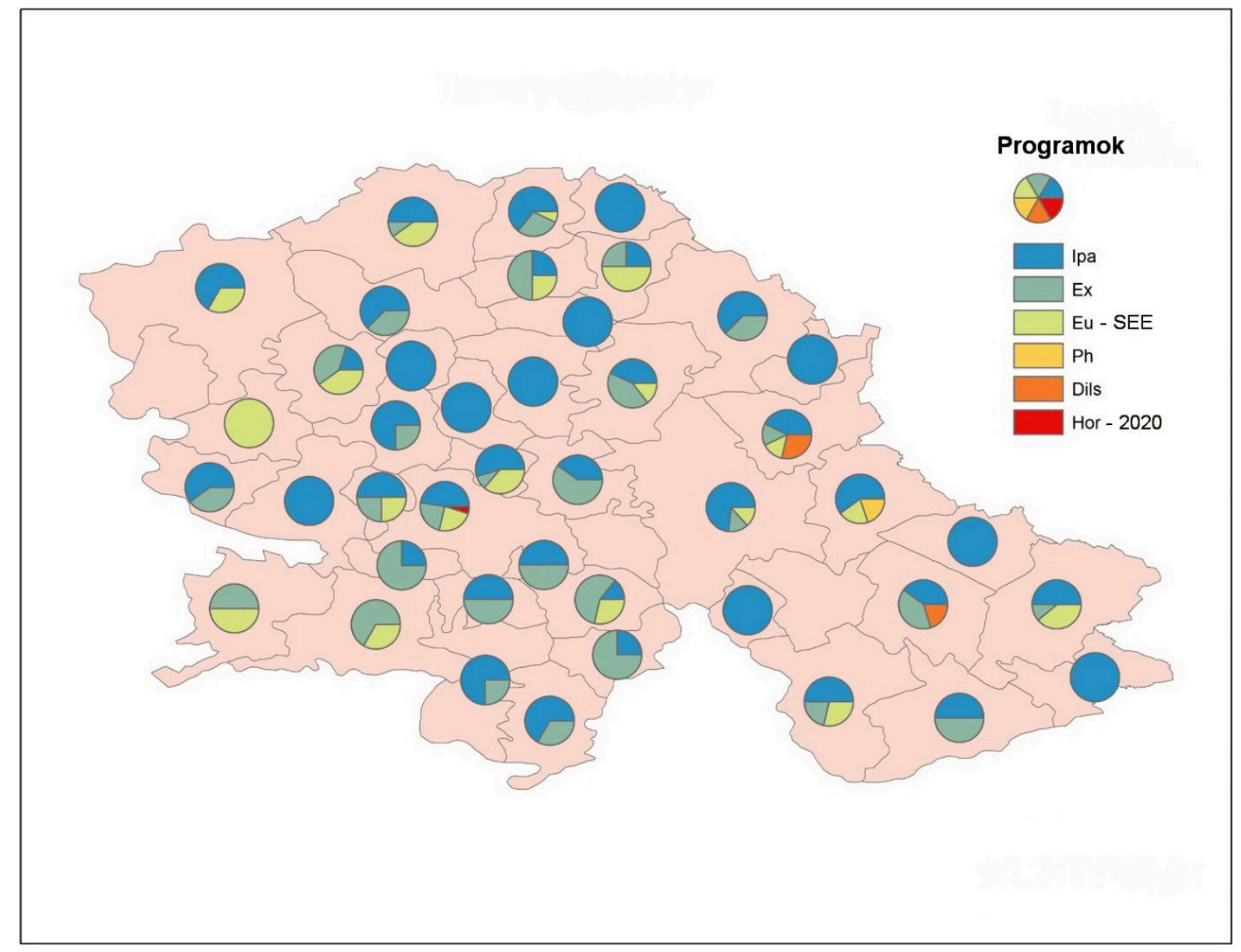

Source: Author based on EUV data

Based on the survey conducted by the Association of Independent Journalists of Vojvodina, the 44 municipalities used mainly IPA 2 (cross-border cooperation support) resources, together with some IPA 1 programmes (EXCHANGE I-IV), while there was considerably smaller interest in other available resources (EUV, 2015). No one has applied, for example, for the European Instrument for Democracy and Human Rights, the Lifelong Learning or the Youth in Action programmes. The Innovation and Competitiveness Framework Programme (CIP) was used only by the City of Novi Sad and the FP7 funds were only applied in Novi Sad and Subotica. Only a few municipalities (Subotica, Ada) applied for Europe for Citizens programme, but there were a lot more successful project applications the EXCHANGE, RSEDP or DILS programmes. 


\section{Evaluation of the EU projects of the municipalities from Vojvodina}

During the research supported by the Regional Co-operation and Local Self-Government Secretariat of Vojvodina, we examined the effectiveness of EU subsidies in the case of 10 municipalities (Nagy-Ricz-Ribár-Nagy, 2015). In this analysis, we used a similar evaluation methodology as in a previous survey - the analysis of applications supported by CARDS and PHARE - after the completion of the 2004-2006 support cycle (Nagy I. - Ricz - Nagy M., 2015; Nagy-Kicosev, 2011). This paper presents the significance and impact of local government projects implemented during 2007-2013 on the basis of the results of the abovementioned studies. The basic questions of the analysis relate to the establishment of partnerships for projects, sustainability of projects, financial and human resource capacity problems related to project implementation, and financial realisation. Moreover, the concrete results of territorial and local development are in focus, as well as to reveal what local governments have learned about the EU and EU funding, and what the other open issues and problems of project generation are.

When assessing the sustainability of projects, the survey was based on the following questions:

- To what extent has the partnership from the project remained after its implementation?

- Was successful project implementation followed by the establishment of new partnership, the formation of a partnership network?

- Do they employ new staff after the project has been implemented and when applying for new projects?

During the deep-drilling analysis of the 10 involved municipalities (Subotica, Pančevo, Zrenjanin, Vršac, Kanjiža, Temerin, Ruma, Bačka Topola, Novi Kneževac and Senta), those data of these towns have been taken into account, which make it possible to assess the effectiveness of the EU subsidies. The evaluation was based on the following indicators:

- The amount of the effective subsidies used by the municipalities (the participation rate of a municipality in each project and the share of the project value allocated to the municipality);

- The financial implementation of the project (this was important because due to refinancing, local governments could only claim the pre-financed support after full financial and content implementation, and it did not always happen). 
The following items were taken into account during the evaluation (the score of sustainability rating is in brackets):

- formal communication with partners after project completion (1),

- joint participation with previous partners in new (unsuccessful) applications (IPA CBC, EXCHANGE and others) (2),

- contact and cooperation with new partners, which can be characterised by a series of discussions followed by several (at least 3) media (3);

- repeated joint (successful) application with previous partners (4),

- submission of successful applications with former and new partners on topics from the 1st or 2nd calls (EXCHANGE, IPA CBC and others) (5) (Nagy-Ricz-Ribár-Nagy, 2015).

During project generation, the partnership significantly determines the implementation of EU principles, the continuation of relations and cooperation. In most cases, the partnership is not finished after the project implementation; the relationship is maintained at protocol level or at the level of new project relations. In some municipalities, financial sustainability of a project depends on the maintenance of previous partnerships, but the lack of human resources can also significantly reduce functional relations between partners.

The phase following the implementation of the projects and the development of partnerships is the process of potential clustering - the involvement of new partners, which can be assessed as a positive consequence of the project generation process. Occasionally, the partnership works successfully apart from the project activities in other forms of cooperation even after the project development and implementation is finished. After the restoration of the Synagogue in Subotica, the investor and constructor partners from Szeged (engineers, architects) were interested in the continuation of the program, and after the construction of Bajmok-Bácsalmás border crossing the Provincial Urban Planning Institute urged further cooperation with the Hungarian partner. 
Figure 2 Values of projects financed from IPA (Component 1 and 2) sources in period 20072013

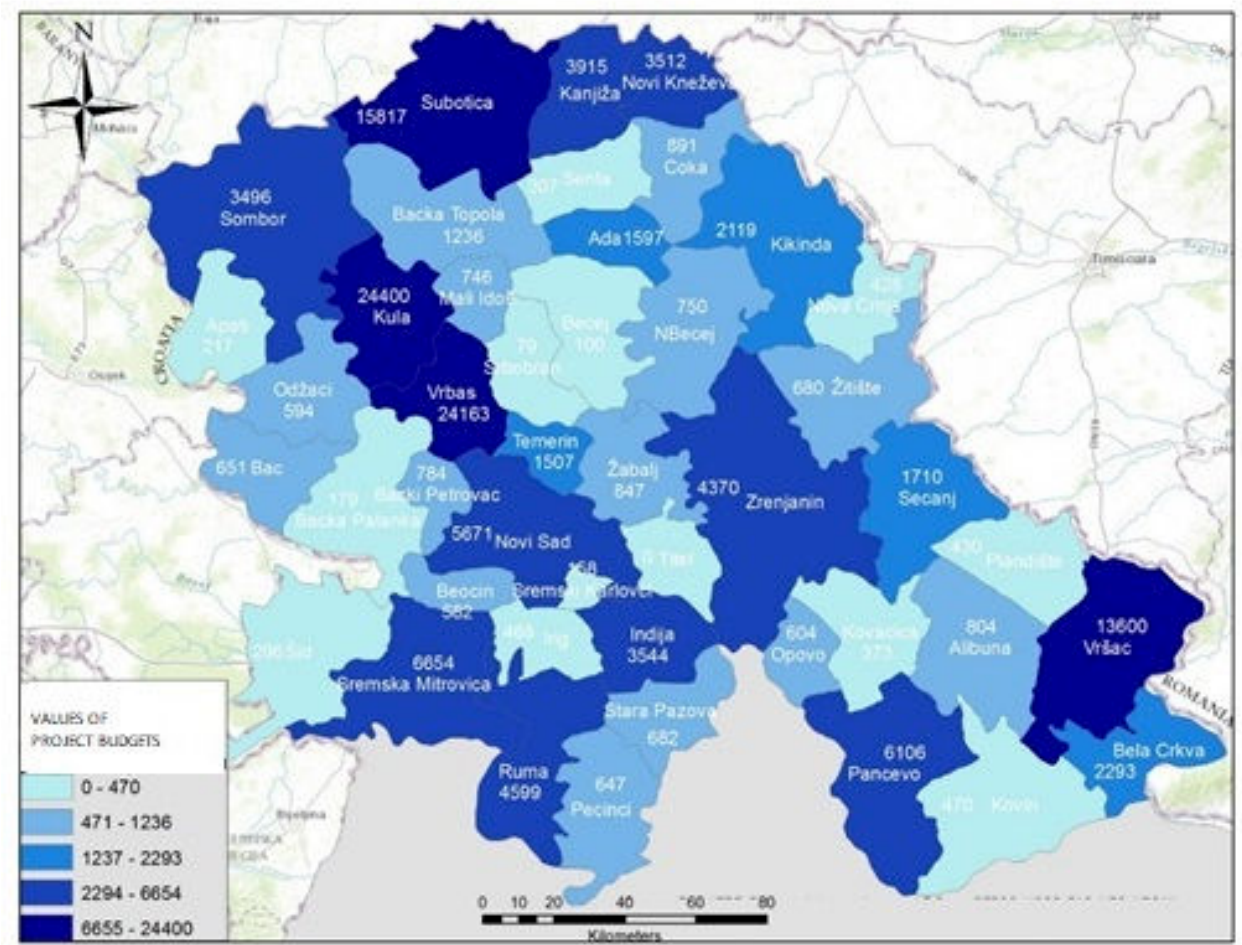

Source: Nadj, 2016

The sustainability of the project means its subsequent development generating effect after its completion. Sustainability can ensure long-term socio-economic utilisation of the project's positive impacts and its incorporation into the development of society. In this respect, all the surveys conducted in Vojvodina show that the projects do not continue after their implementation.

Sustainability can be followed only in $50 \%$ of the realised projects of the examined municipalities, and the immanent impact of these projects can be achieved in the medium term: local authorities have recognised the institutions created by CARDS and IPA, their importance in regional development and their integration into the local government system. These institutions continue to operate as development agencies.

Tracking sustainability of infrastructure projects was much easier since the investments were completed after several cycles (planning, construction). Some of these exemplary investments are the river border crossing and customs office on the Tisa in Kanjiža, bicycle trails between Tiszasziget (HU) - state border - Novi Kneževac (SRB), market hall in Vršac with food testing laboratory (the latter is still not in use).

The series of negative examples includes a number of EXCHANGE programme projects, which were intended to assist local authorities with the introduction of information 
technology (e-administration, application of geographic information systems etc.), but were not involved in everyday use. Employees themselves whose work would have been helped by the development did not support its introduction because, on the one hand, they should have learned the IT basics and, on the other hand, they would have been subject to constant monitoring. A SEE project of urban development also ended unsuccessfully as it was not supported by the local office of urban development because it did not consider the international research team to be competent to assess such a local development opinion.

Based on the survey with the sustainability indicators used above, it can be stated that the sustainability indicators of the projects of the examined municipalities was between 1.25 and 3.25 , despite the fact that the financial realisation reached $80-100 \%$.

In terms of financial realisation, the majority of the examined towns scored $80-100 \%$. Reduced financial closures can be triggered by bank transactions and exchange rate fluctuations, but they are often due to shortcomings in tenders, causing reduced reimbursement of pre-financed items. Most of the municipalities succeeded in acquiring the $15 \%$ of own contribution required from the applicants, as a subsidy of the Financial Secretariat of the Government of Vojvodina, thus fulfilling the contracted amount.

Based on the opinion of project participants, the following conclusions can be drawn from the implementation of the EU funds in the municipalities of Vojvodina:

- Project writing, participation in EU projects, project implementation in local governments depends to a large extent on the willingness of individuals to initiate, from the responsible administrative leaders in local governments or from those who see a chance in certain issues of EU regional policy;

- It is difficult to force municipal subjects to deal with project writing if it is not their job;

- Project designers and implementers have to work overtime without any financial implications;

- The project writers do not see themselves in the topics of the calls;

- The project designers do not see the importance of the development of local government;

- They work as a volunteer or employ others;

- There is no proper political interest behind the project generation;

- Often these projects are considered as sources of money laundering in local governments; 
- They do not recognise the importance of the resources necessary for the implementation of strategic plans, and for education and training;

- Municipal employees have no capacity for project writing and / or do not know the language of project proposals (English);

- Or they do not know the national and European legal-strategic frameworks and documents.

As a conclusion we can say that although substantial sums were invested from the above mentioned resources into the economy of Vojvodina for its development, the main indicator the GDP - has been increasing only slightly, while these projects have no effects on decreasing unemployment. In the overall economic situation, unemployment is primarily decreased by emigration, in which Vojvodina Hungarians take part at a rate above the average compared to their headcount, thus decreasing the economic power of the community through emigration (Ricz, 2012).

The national strategies, the provincial and municipal development plans that incorporate European principles are missing harmonisation and the ensuring of adequate resources, and they lack a sound and coherent economic vision. In the past planning periods there was not established an adequate consistency of policies or harmonisation of development, which could have resulted in a unified economic development policy and thus bringing slow economic growth.

In spite of the fact that in the preparation of the described EU programmes economic development received expressed priority, in practice there was no considerable economic development. And while successful projects were correctly implemented in most cases, it was impossible to indicate their long-term effects beside short-term impacts, since many of them were only "soft" projects.

Additional problems of the projects are in connection with the lack of human, material and organisational capacities, as well as with some difficulties concerning administrative procedures (EUV, 2015).

\section{REFERENCES}

EUV - EVROPA u Vojvodini: pogled i analiza realizovanih projekata lokalnih samouprava na teritoriji AP Vojvodine finansiranih od strane EU u programskom periodu 2007-2013. Novi Sad, Nezavisno društvo novinara Vojvodine. p. 160. (2015)

Mikloš, N. (2016). Apsorpcioni kapaciteti vojvođanskih lokalnih samouprava u odnosu na pretpristupne fondove, Master rad. Novi Sad, Fakultet Tehničkih Nauka 
Nagy, I., Ricz, A., \& Nagy, M. (2015). Az INTERREG IIIA - CARDS (CBC) támogatások földrajzi sajátosságai és hatásai a helyi és területi fejlődésre a Vajdaság AT határrégióiban, 2004-2006 In: Ricz A , Takács Z (szerk.) A régió TÍZpróbája. 296 p. Szabadka: Regionális Tudományi Társaság/Društvo za Regionalne Nauke, pp. 101112. (ISBN:978-86-86929-06-8)

Nagy, I., Ricz, A., Ribár, Gy., \& Nagy, M. (2015). Spremnost i pripremljenost lokalnih samouprava AP Vojvodine za prijem $i$ korišćenje razvojnih fondova Evropske unije Temerin: Prospero-Temerinske novine. 70 p. (ISBN:978-86-919029-0-2)

Nagy I., \& Kicosev S. (2011). Geographical characteristics of the distribution of the INTERREG and IPA funds, and their effects on the development of the border regions of Vojvodina In: BRIT XI Mobile borders. Paper Session 14. Multi Scalar Perspectives of Mobile Borders Governance.

Ricz, A., Nagy, I., \& Juhász, B. (2015). A Vajdaságban elérhető gazdaságfejlesztési eszközök és az azok által elért eredmények. In: Fábián A , Bertalan L (szerk.) Otthon a Kárpátmedencében: Területfejlesztési Szabadegyetem 2011-2015. 528 p. Sopron: Nyugatmagyarországi Egyetem Kiadó, pp. 389-414. (ISBN:978-963-334-276-3)

Ricz, A., \& Nagy I. (2014). A határon átívelő programok területi dimenziói a Vajdaságban In: Takács Z., \& Ricz, A. (szerk.) Regionális kaleidoszkóp, 387 p. Szabadka: Regionális Tudományi Társaság, pp. 115-122. (ISBN:978-86-86929-05-1).

Ricz, A. (2012). A határon átívelő programok hatásai Vajdaság területi fejlődésére - az ezeken alapuló területi együttműködések továbbfejlesztésének lehetősei In: Északmagyarországi Stratégiai Füzetek, 2012. IX. évfolyam 1. szám, Miskolc. 